\section{Partisipasi Masyarakat Dalam Pembangunan Infrastruktur Jalan Di Desa Kaligintung Kecamatan Temon Kabupaten Kulon Progo 2019}

\author{
Ismatullah ${ }^{1)}$, Gerry Katon Mahendra2) * \\ ${ }^{1}$ Program Studi Administrasi Publik, \\ Universitas 'Aisyiyah Yogyakarta. \\ ${ }^{2}$ Program Studi Administrasi Publik, \\ Universitas ‘Aisyiyah Yogyakarta. \\ * Korespondensi Penulis. E-mail: \\ gerrykatonvw@gmail.com
}

\begin{abstract}
Abstrak
Undang-undang No 23 tahun 2014 pasal 1 ayat 41 menjelaskan bahwa partisipasi masyarakat adalah sebuah peran serta masyarakat dalam menyalurkan aspirasi, pemikiran dan kepentingan dalam penyelenggaraan pemerintah daerah. Partisipasi masyarakat dalam subjek pembangunan merupakan upaya untuk mewujudkan tujuan pembangunan nasional.. Dalam hal ini, penelitian ini akan membahas tentang partisipasi masyarakat dalam pembangunan infrastruktur jalan di Desa Kaligintung Kecamatan Temon Kabupaten Kulon Progo 2019. Terdapat empat jenis partisipasi di Desa Kaligintung yaitu (1) partisipasi dalam pengambilan keputusan, (2) partisipasi dalam pelaksanaan, (3) partisipasi dalam pengambilan manfaat dan (4) partisipasi dalam evaluasi. Selanjutnya faktor partisipasi masayarakat dalam pembangunan infrastruktur di Desa Kaligintung dipengaruhi oleh beberapa faktor pendukung dan terdapat pula faktor penghambat. Pada faktor pendukung terdapat tiga faktor yaitu faktor ekonomi, faktor kesadaran, faktor pendidikan. Sedangkan faktor penghambatnya adalah menggunakan bahu jalan desa untuk
\end{abstract}

kepentingan pribadi, namun faktor ini tidak menjadikan tertundanya pembangunan infrastruktur jalan Desa Kaligintung.

Kata kunci: Partisipasi masyarakat, Infrastruktur jalan

\section{Community Participation in Road Infrastructure Development in Kaligintung Village, Temon District, Kulon Progo Regency 2019}

\begin{abstract}
Law No. 23 of 2014 article 1 paragraph 41 explains that community participation is a community participation in channeling aspirations, thoughts and interests in the administration of local government. Community participation in the subject of development is an effort to realize national development goals. In this case, this study will discuss community participation in road infrastructure development in Kaligintung Village, Temon District, Kulon Progo Regency 2019. There are four types of participation in Kaligintung Village, namely (1) participation in decision making, (2) participation in implementation, (3) participation in benefit-taking and (4) participation in evaluation. Furthermore, the community participation factor in infrastructure development in Kaligintung Village is influenced by several supporting factors and there are also inhibiting factors. There are three supporting factors, namely economic factors, awareness factors, and education factors. While the inhibiting factor is using the shoulder of the village road for personal interests, but this factor does not delay the construction of the Kaligintung Village road infrastructure.
\end{abstract}

Keywords: Community participation, road infrastructure 
JSPG: Journal of Social Politics and Governance Vol.3 No.1 Juni 2021

\section{A. PENDAHULUAN}

Pembangunan suatu negara pada hakekatnya memiliki tujuan untuk mensejahterahkan masyarakat, sebagaimana yang tertuang dalam pembukaan Undang-Undang Dasar 1945 alenia IV yang berbunyi, pembangunan nasional merupakan suatu tujuan bangsa Indonesia dalam melindungi segenap bangsa dan seluruh tumpah darah Indonesia, serta memajukan kesejahteraan umum dan ikut serta dalam melaksanakan ketertiban dunia. Pembangunan nasional dapat terwujud untuk mewujudkan tujuan pembangunan harus dilaksanakanya pembangunan nasional, baik itu pembangunan sumber daya manusia (SDM), sumber daya alam (SDA), serta pembangunan infrastruktur untuk meningkatkan dan memudahkan perekonomian secara nasional maupun daerah. Undang-undang No 6 tahun 2014, pemeritah memiliki kewenangan untuk mengatur dan menata wilayahnya, salah satunya adalah pembangunan infrastruktur atau sarana dan prasarana yang di butuhkan oleh masyarakat. Dikarenakan desa dengan pembangunan infrastruktur yang memadai dan menunjang kebutuhan masyarakatnya dapat dikatakan desa yang maju.

Indeks Pembangunan Desa (IPD) Provinsi Daerah Istimewa Yogyakarta tahun 2018 menurut data BPS adalah 73,32\% (BPS DIY, 2018), lebih tinggi dibandingkan rata-rata IPD secara nasional 59,36\%. Daerah Istimewa Yogyakarta memiliki jumlah desa sebanyak 392 desa, dibagi menjadi dua kategori desa mandiri sebanyak 158 desa dengan persentase $40,31 \%$ sedangkan desa berkembang sebanyak 234 desa dengan persentase 59,69\%. Lebih lanjut data BPS tahun 2018 juga menunjukkan bahwa Daerah Istimewa Yogyakarta merupakan salah satu daerah yang sudah tidak memiliki desa tertinggal.
Provinsi Daerah Istimewa Yogyakarta memiliki nilai rata-rata Indeks Pembangunan Desa yang tertinggi adalah Kabupaten Bantul sebesar 76,13\% dengan jumlah 75 desa, dibagi menjadi dua kategori yaitu desa mandiri sebanyak 42 desa dan 32 desa merupakan desa berkembang. Diikuti Kabupaten Sleman dengan presentase 75,93\%, Kota Yogyakarta dengan presentase 73,32\% dan Kabupaten Kulon Progo sebanyak 72,10\%. Sedangkan Indeks Pembangunan Desa terendah berada di Kabupaten Gunung Kidul sebesar 71,02\%, dengan jumlah 144 desa, 41 diantarnya sudah termasuk desa mandiri dan 103 desa lainnya masih termasuk kategori desa berkembang.

Berdasarkan penelitian terdahulu juga dapat dijadikan gambaran an pemetaan terkait upaya kebaruan yang akan dihadirkan dalam penelitian ini. Terdapat penelitian berjudul analisis partisipasi masyarakat dalam pembangunan infrastruktur di Desa Pao Kecamatan Melangke Barat Kabupaten Luwu Utara (Karina, 2017). Penelitian ini bertujuan untuk mengetahui bagaimana partisipasi masyarakat dalam pembangunan infrastruktur jalan di Desa Pao, dengan melihat faktor pendukung dan penghambat partisipasi masyarakat terhadap pelaksanaan pembangunan. Hasil dari penelitian ini menunjukkan bahwa Partisipasi masyarakat dalam pembangunan infrastruktur jalan cukup baik, yakni terdapat dua hal yang mempengaruhi. Pertama, adanya kesadaran masyarakat untuk turut berpartisipasi dengan membebaskan lahannya. Selain itu, partisipasi masyarakat dalam pembangunan dapat dilihat dengan bentuk swadaya masyarakat baik dalam hal tenaga ataupun dalam bentuk materi. Kedua, pembangunan infrastruktur jalan di Desa Pao dipengaruhi oleh faktor 
JSPG: Journal of Social Politics and Governance Vol.3 No.1 Juni 2021

pendukung diantaranya yaitu sumbangan dan dukungan masyarakat serta faktor kesadaran atau kemauan. Sedangkan faktor penghambatnya yaitu adanya dana dasa dan rendahnya tingkat pendidikan masyarakat.

Lebih lanjut, terdapat penelitian berjudul Partisipasi Masyarakat dalam Pembangunan Infrastruktur di Desa Sinarsari Kecamatan Kalirejo Kabupaten Lampung Tengah (Rahayu, 2018). Penelitian ini bertujuan untuk mengetahui dan menganalisis partisipasi masyarakat dalam pembangunan infrastruktur dengan melihat faktor pendukung partisipasi masyarakat terhadap pelaksanaan pembangunan di Desa Sinarsari. Hasil dari penelitian ini menunjukkan bahwa partisipasi masyarakat Desa Sinarsari dalam pembangunan infrastruktur cukup baik, karena masyarakat memberikan bantuan berupa tenaga, dan pemikiran. Hal ini menunjukkan bahwa hampir keseluruhan anggota masyarakat mengetahui dan aktif dalam rangkaian kegiatan pada pembangunan infrastruktur. Terdapat beberapa hal yang mempengaruhi masyarakat dalam berpartisipasi, diantaranya adanya sosialisasi, kesempatan, dan faktor pemimpin. Dengan demikian, kebaruan yang akan dicapai dalam penelitian ini terutama terkait dengan objek penelitian dan pola partisipasi yang berdasarkan karakter daerah dan masyarakatnya serta bentuk dukungan pemerintah yang diharapkan hadir bersinergi dengan keinginan masyarakat.

Desa Kaligintung merupakan salah satu desa yang ada di Kabupaten Kulon Progo, desa ini secara geografis terletak sekitar $10 \mathrm{~km}$ dari sebelah barat kota wates dengan jumlah penduduk 500 kepala keluarga. Desa Kaligintung memiliki objek wisata religi yaitu makam girigondo yang merupakan tempat pemakaman keluarga paku alam Yogyakarta. Desa kaligintung memiliki keunikan dan budaya masyarakat yang sangat kental, sehingga masyarakatnya masih menanamkan nilainilai gotong royong yang sangat baik. Tingkat partisipasi di Desa Kaligintung ini dibuktikan dengan banyaknya masyarakat yang aktif dalam musyawarah didesa, akan tetapi pembangunan didesa ini terkandala dengan kurangnya dukungan yang belum maksimal dari pihak pemerintah desa. Desa Kaligintung merupakan desa yang masih berkembang, peneliti melihat diperlukannya adanya keselarasan antara pemerintah desa, dengan masyarakat desa kaligintung sehingga adanya perhatian dan terlaksananya pembangunan yang merata di desa ini. Karena jika dilihat dari potensi masyarakat di Desa Kaligintung sangat baik dalam aspek sosial, budaya, dan pariwisata. Desa Kaliguntung memiliki infrastruktur yang dibangun secara swadaya masyarakat. Partisipasi masyarakat sangat diperlukan dalam pembangunan infrastruktur didaerah guna memberi masukan terhadap pemerintah untuk mengetahui apa saja yang dibutuhkan oleh masyarakat. Kemandirian masyarakat Desa Kaligintung dalam membangun infrastruktur secara mandiri dapat menjadikan Desa Kaligintung mencapai tujuan yang diharapkan sehingga terwujudnya partisipasi masyarakat secara menyeluruh yang melibatkan seluruh elemen masyarakat di Desa Kaligintung. Adapun, fokus analisis yang akan dicapai dalam penelitian ini mengarah pada analisis pola partisipasi masyarakat yang bersinergi dengan program pemerintah Desa. Pola tersebut akan dianalisis berdasarkan karakter daerah dan masyarakat yang tentu akan menghasilkan suatu nilai khas. 
JSPG: Journal of Social Politics and Governance Vol.3 No.1 Juni 2021

\section{B. TEORI (Literature Review)}

1. Partisipasi Masyarakat

Partisipasi secara sederhana dapat diartikan sebagai keikutsertaan seseorang/kelompok masyarakat dalam program pembangunan, mulai dari perencanaan sampai tahap evaluasi sehingga dapat menunjang keberhasilan program pembangunan dengan berbagai bentuk dan jenis partisipasi. Bentuk partisipasi yang dimaksud seperti partisipasi buah pikiran yang diberikan pada pertemuan atau rapat, partisipasi jasa/tenaga yang diberikan partisipan dalam berbagai kegiatan untuk perbaikan atau pembangunan desa, pertolongan bagi orang lain, partisipasi harta benda yang mana diberikan oleh partisipan dalam bentuk uang, makanan atau yang lainnya, partisipasi keterampilan dan kemahiran yang diberikan orang untuk mendorong aneka ragam bentuk usaha dan industry, partisipasi sosial yang diberikan orang sebagai tanda keguyuban (Huraerah, 2008). Menurut Cohen dan Uphoff membedakan partisipasi menjadi empat jenis (Kalesaran, 2015), yaitu 1) Partisipasi dalam pengambilan keputusan. Partisipasi dalam pengambilan keputusan ini berkaitan dengan pengambilan keputusan dimasyarakat antara lain seperti ikut menyumbangkan gagasan atau pemikiran, kehadiran dalam rapat, diskusi dan tanggapan atau penolakan terhadap program yang ditawarkan sehingga mendapatkan hasil yang mufakat. 2) Partisipasi dalam pelaksanaan. Partisipasi dalam pelaksanaan meliputi menggerakkan sumber dana, kegiatan administrasi koordinasi, dan penjabaran program. Partisipasi ini merupakan lanjutan rencana yang telah digagas yang berkaitan dengan perencanaan, pelaksanaan dan tujuan. 3) Partisipasi dalam pengambilan manfaat. Partisipasi ini tidak lepas dari hasil pelaksanaan yang telah dicapai baik yang

berkaitan dengan kualitas maupun kuantitas. 4) Partisipasi dalam evaluasi. Partisipasi ini berkaitan dengan mengetahui tercapainya program yang sudah direncanakan sebelumnya. Tahap evaluasi, dianggap penting sebab partisipasi masyarakat pada tahap ini dianggap sebagai umpan balik yang dapat memberikan masukan demi perbaikan pelaksanaan kegiatan selanjutnya.

\section{Pembangunan}

Hakekat pembangunan adalah proses perubahan yang terus menerus yang merupakan kemajuan dan perbaikan menuju kearah yang ingin dicapai. Menurut Siagian, pembangunan adalah suatu usaha atau rangkaian usaha pertumbuhan dan perubahan berencana yang dilakukan secara sadar oleh suatu bangsa, Negara dan pemerintah menuju modernitas dalam rangka pembinaan bangsa (Wahyuddin, 2018). Adapun, tujuan dari pembangunan adalah untuk memberikan kehidupan yang lebih makmur dan sejahtera bagi masyarakat, dalam upaya pembangunan partisipasi masyarakat mempunyai peran yang sangat penting karena pembangunan ditujukan untuk memenuhi kebutuhan masyarakat (Karina, 2017). Adapun, Infrastruktur adalah suatu istilah yang digunakan untuk menggambarkan fasilitas yang disediakan atau sengaja dibuat untuk mendukung aktifitas atau kegiatan masyarakat. Infrastruktur biasanya menjadi program yang diprioritaskan oleh pemerintah, baik itu pusat maupun daerah sehingga program infrastruktur selalu di programkan untuk menunjang kegiatan masyarakat sehingga meningkatkan perekonomian dan kesejahteraan.

\section{Pemerintah Desa}

Menurut Surbakti, pemerintah secara etimologis berasal dari kata yunani adalah 'kubernan' atau nahkoda kapal, artinya menatap kedepan (Rahman, 2018). 
JSPG: Journal of Social Politics and Governance Vol.3 No.1 Juni 2021

Selain itu, dijelaskan bahwa pemerintah dari kata 'perintah' (Martini dan Juwono, 2015). Kata perintah memiliki empat unsur yakni pertama, ada dua pihak yang saling terikat. Kedua, kedua belah pihak saling memiliki hubungan kontraktual. Ketiga, pihak yang memerintah memiliki kewenangan. Keempat, pihak yang diperintah memiliki ketaatan. Desa secara etimologi berasal dari bahasa sansekerta, deca yang berarti tanah air, tanah asal atau tanah kelahiran. Sedangkan menurut undang-undang no 6 tahun 2014 tentang desa pasal 1 ayat 1 , desa merupakan satu kesatuan masyarakat hukum yang memiliki batas wilayah yang berwenang untuk mengatur dan mengurus urusan pemerintahan, kepentingan masyarakat di desa setempat berdasarkan prakasa masyarakat serta hak asal usul, atau hak adat tradisional yang di akui dan di hormati oleh sistem pemerintahan Negara kesatuan republik Indonesia. Menurut undang-undang No. 6 tahun 2014 pasal 25 . Pemerintah Desa adalah kepala Desa atau yang disebut dengan nama lain dan yang dibantu oleh perangkat desa atau yang disebut dengan nama lain. Urusan pemerintahan desa dan badan pemusyawaratan desa dalam mengatur dan mengurus kepentingan masyarakat setempat sesuai dengan hak asal usul dan adat istiadat desa yang diakui dan dihormati dalam sistem pemerintahan Negara Kesatuan Republik Indonesia (Kansil, 2005).

\section{METODE}

Pada penelitan ini menggunakan tipe penelitian kualitatif dengan jenis penelitian deskriptif. Menurut Bogdan dan taylor dalam (Moleong. Lexy J, 2017) jenis penelitian ini berupaya menggambarkan kejadian atau fenomena sesuai dengan apa yang terjadi dilapangan, serta data yang dihasilkan berupa kata-kata tertulis atau lisan dari orang-orang dan perilaku yang dapat diamati. sedangkan menurut (Sugiyono, 2016) mendefinisikan metode penelitian kualitatif sebagai metode penelitian yang berlandaskan pada filsafat postpositivisme, digunakan untuk meneliti pada kondisi obyek yang alamiah.

Dalam penelitian ini menggunakan teknik pengumpulan data berupa observasi, wawancara, penelitian kepustakaan (Library research), dan dokumentasi. Peneliti melakukan observasi pada kurun waktu yang telah ditentukan dengan melihat kondisi dan keadaan di lingkungan penelitian. Dalam hal ini wawancara dilakukan dengan menjaga jarak antara peneliti dengan responden dan kegiatannya dilakukan secara lisan dan tatap muka. Wawancara dilakukan dengan mengajukan pertanyaan-pertanyaan kebeberapa responden yaitu: (1) Kepala Desa Kaligintung, (2) BPD Kaligintung , (3) Tokoh Masyarakat, dan (4) Masyarakat Desa Kaligintung.

Alur yang digunakan adalah peneliti melakukan observasi mengenai karakter wilayah dan masyarakat, kemudian dilanjutkan dengan wawancara kepada narasumber untuk menggali data relevan mengenai pola partisipasi yang dijalankan. Disamping itu diperkuat dengan menyadur data yang melalui dokumentasi yang ada. Hasil dari proses tersebut secara operasional kemudian akan dipilah sesuai relevansi dan kemudian dianalisis berdasarkan teori yang digunakan dan kerangka pikir yang diadopis. Secara umum, rangkaian teknik tersebut dianggap sangat sesuai dengan tema dan karakter narasumber yang dihadapi di lapangan. 
JSPG: Journal of Social Politics and Governance Vol.3 No.1 Juni 2021

\section{HASIL DAN PEMBAHASAN}

Desa Kaligintung merupakan salah satu desa yang berada di kebupaten Kulon Progo yang telah berdiri sejak zaman akhir pada masa kerajaan majapahit, kurang lebih pada abad ke-XIV. Secara topografi Desa Kaligintung memiliki ketinggian tanah rata-rata 500meter diatas permukaan laut dengan luas desa 226,270 Ha dengan rincian pemukiman $100,2070 \mathrm{Ha}$, tanah sawah teririgasi $69,6450 \mathrm{Ha}$ dan tanah sawah tadah hujan $17,7225 \mathrm{Ha}$ dan mayoritas penduduknya berprofesi sebagai petani serta meliliki lima padukuhan.
Sehingga pembangunan infrastruktur jalan desa sangat penting guna untuk menunjang berjalannya kegiatan ekonomi masyarakat. Oleh karena itu, pada proses pembangunan infrastruktur jalan Desa Kaligintung banyak melibatkan partisipasi dari masyarakat, ini didasarkan pada data yang sudah tertera pada tabel dibawah ini. Adapun proses pembangunan yang sudah dilakukan Desa Kaligintung dalam 10 tahun terakhir dapat dilihat pada tabel sejarah pembangunan yang tertera dibawah ini.

Tabel 1. Kegiatan Pembangunan Desa Kaligintung

\begin{tabular}{|c|c|l|c|}
\hline No & Tahun & \multicolumn{1}{|c|}{ Kegiatan Pembangunan } & Ket \\
\hline 1 & 2011 & Pembangunan Cor blok jalan dusun & \\
\hline 2 & 2011 & Pengadaan penerangan jalan & \\
\hline 3 & 2011 & Pembangunan gorong - gorong kulon dusun sidatan & \\
\hline 4 & 2012 & Pemasangan kantor keramik desa & \\
\hline 5 & 2012 & Pembangunan kios desa & \\
\hline 6 & 2012 & Pembangunan jembatan darurat Bencana alam & \\
\hline 7 & 2012 & Rehabilitas gedung PKK & \\
\hline 8 & 2012 & Pembangunan gedung LKM & \\
\hline 9 & 2013 & Rehabilitas balai desa & APBDesa \\
\hline 10 & 2013 & Pembangunan irigasi dusun sidatan & APBDesa \\
\hline 11 & 2019 & Pembangunan Sanitasi dusun Balong & \\
\hline 12 & 2019 & Pembangunan Jalan dusun Kaligintung Lor & \\
\hline
\end{tabular}

Sumber Data: Profil Desa Kaligintung Tahun 2020

\section{PARTISIPASI MASYARAKAT DALAM PEMBANGUNAN INFRASTRUKTUR DI DESA KALIGINTUNG KECAMATAN TEMON KABUPATEN KULON PROGO}

Pertama, partisipasi dalam pengambilan keputusan berkaitan dengan pengambilan keputusan di masyarakat, antara lain seperti ikut menyumbangkan gagasan atau pemikiran, kehadiran dalam rapat, diskusi dan tanggapan atau penolakan terhadap program yang ditawarkan sehingga mendapatkan hasil yang mufakat (Kalesaran, 2015). Jika merujuk penelitian terdahulu bahwa terdapat tiga kategori untuk mengukur tingkat partisipasi yaitu: partisipasi masyarakat tingkat tinggi, partisipasi masyarakat tingkat sedang dan partisipasi masyarakat tingkat rendah, dimulai dari perencanaan, pelaksanaan, dan pemeliharaan dilihat dari keaktifan sampai dengan tidak aktif (Kogoya, 2015). Karakteristik desa yang ditinjau dari aspek ekonomi, sosial, budaya, dan geografi serta tingkat pendidikan masyarakat memiliki korelasi terhadap tinggi rendahnya tingkat partisipasi masyarakat. Partisipasi masyarakat di seluruh desa memiliki 
JSPG: Journal of Social Politics and Governance Vol.3 No.1 Juni 2021

bentuk yang seragam yaitu partisipasi dalam bentuk sumbangan tenaga, material, dan danaDari hasil penelitian dapat disimpulkan bahwa, pengambilan keputusan merupakan hal penting yang akan menentukan bentuk partisipasi masyarakat. Menurut Wilcox terdapat lima tingkatan dalam "pengambilan keputusan" (Aprilia Theresia, 2015), diantaranya (1) Memberikan informasi. (2) Konsultasi yaitu menawarkan pendapat sebagaimana pendengar yang baik dapat memberikan umpan balik, akan tetapi tidak terlibat dalam implementasi ide dan gagasan. (3) Pengambilan keputusan bersama dalam arti memberikan dukungan terhadap ide, gagasan, serta mengembangkan peluang yang diperlukan guna pengambilan keputusan. (4) Bertindak bersama, merupakan keterlibatan dan ikut menjalin kemitraan dalam pelaksanaan kegiatannya. (5) Memberikan dukungan, dimana masyarakat lokal menawarkan pendanaan, nasehat, dan dukungan lain untuk mengembangkan dan menjalankan program kegiatan. Apabila melihat teori tersebut, dengan mangacu point ketiga menunjukkan bahwa pengambilan keputusan berarti memberikan dukungan terhadap ide, gagasan, serta mengembangkan peluang yang diperlukan guna pengambilan keputusan dan bertindak bersama. Keterlibatan ini dibuktikan bahwa masyarakat Desa Kaligintung memiliki kerjasama yang baik dengan pemerintahan desa, hal ini dapat dilihat dari bentuk partisipasi dalam pembangunan jalan Desa Kaligintung.

Selanjutnya, partisipasi masyarakat dalam bentuk pelaksanaan, merupakan ide atau gagasan penting yang harus dimunculkan, khususnya untuk pembangunan infrastrukur jalan. Biasanya masyarakat Desa Kaligintung menyampaikan partisipasinya diwaktu musyawarah, yang diadakan langsung oleh ketua padukuhan, dimana ide atau gagasan tersebut kemudian disampaikan ke perangakat desa. Hal ini menunjukkan bahwa peran padukuhan dalam menyampaikan ide ataupun gagasan dari masyarakat, kepada pemerintahan desa, dapat dilakukan dengan baik. Adapun pembuktiannya yaitu dengan adanya pelaksanaan pembangunan infrastrukur jalan desa. Sehingga partisipasi masyarakat berkaitan sangat dengan tercapainya dan terlaksanannya suatu program yang sudah direncanakan sebelumnya, tentunya dengan bantuan beberapa pihak masyarakat yang turut ikut andil untuk berpartisipasi. Sehingga, hasil yang didapatkan dalam wawancara tersebut ada kesesuaian dengan teori yang diungkapkan oleh Cohen dan Uphoff terkait partisipasi dalam pelaksanaan.

Lebih lanjut, partisipasi masyarakat khususnya dalam membangun infrastruktur jalan Desa Kaligintung, ada juga yang berupa tenaga. Artinya, partisipasi dalam pengambilan manfaat sangat berperan penting, sepertihalnya masyarakat desa dapat ikut andil secara langsung untuk membantu proses penyelesaian pembangunan infrastruktur, yaitu dengan cara terjun atau turun langsung ke lapangan. Partisipasi masyarakat desa dalam pelaksanaan pembangunan meliputi; adanya sumber dana, kegiatan admisnistrasi dan koordinasi. Partisipasi ini merupakan lanjutan rencana yang telah digagas, baik berkaitan dengan rencana pelaksanaan maupun tujuan dari perencanaan. Oleh karenanya, bertindak bersama-sama atau gotong royong merupakan salah satu bentuk keterlibatan untuk melancarkan sebuah rencana. Berdasarkan hasil penelitian, dukungan dari masyarakat terlihat bukan hanya tentang pendanaan, nasihat atau pemikiran lainnya. Melainkan untuk mengembangkan dan menjalankan 
JSPG: Journal of Social Politics and Governance Vol.3 No.1 Juni 2021

program kegiatan, masyarakat Desa Kaligintung sangat antusias, dengan cara memberikan kekuatan tenaga ataupun fisiknya untuk kelancaran pembangunan infrastruktur. Oleh karena itu, dengan adanya pembangunan infrastruktur jalan Desa Kaligintung, tentunya dapat memberikan dampak positif kepada individu-individu masyarakat, dan dapat juga menumbuhkan rasa kepekaan sosial terhadap keadaan sekitar. Beberapa informan memberikan informasi, khususnya kepada masyarakat yang berpartisipasi dalam bentuk tenaga, dalam hal ini partisipasi masyarakat dapat dikatakan sangat baik. Hal ini dibuktikan dengan kesatuan atau kekompakan masyarakat penduduk Desa Kaligintung yang memiliki identitas dan budaya yang sama, serta cenderung mengikuti gaya hidup dengan watak budaya yang sama. Sehingga mereka saling mengenal dengan baik antar satu sama lain, dan arah kehidupan mereka dapat dikatakan relatif homogen. Berdasarkan teori dari Soetrisno menjelaskan bahwa salah satu bentuk modal yang terpenting adalah partisipasi sosial masyarakat, dimana masyarakat dapat berpartisipasi dalam pembangunan, sebagai kemauan dari masyarakat sendiri, untuk mendukung secara mutlak programprogram dari pemerintah yang dirancang dan ditentukan tujuannya oleh pemerintah (Wahyuddin, 2018).

Menurut Cohen dan Uphoff, partisipasi dalam evaluasi berkaitan dengan mengetahui tercapainya program yang sudah direncanakan sebelumnya (Kalesaran, 2015). Tahap evaluasi, dianggap penting sebab partisipasi masyarakat pada tahap ini dianggap sebagai umpan balik yang dapat memberikan masukan demi perbaikan pelaksanaan kegiatan selanjutnya. Sehingga, dengan adanya tahap evaluasi ini, masyarakat dapat memberikan masukan, yaitu untuk perbaikan desa menuju lebih baik. Dari hasil penelitian, dapat disimpulkan bahwa pada tahap evaluasi yang berperan aktif dalam hal evaluasi pembangunan infrastruktur Desa Kaligintung adalah masyarakat yang ikut andil dan rapat langsung dengan padukuhan setempat. Namun tidak bisa disangkal, masyarakat umum Desa Kaligintung ternyata juga dilibatkan dalam hal pengawasan, karena ini merupakan salah satu hal penting dalam setiap pembangunan, supaya pembangunan infrastruktur menjadi lebih baik dan tentunya tidak terjadi suatu problem yang berkelanjutan antar masyarakat. Hasil penelitian ini menggambarkan bahwa Keberhasilan pembangunan sebuah infrastruktur, khususnya tidak dapat dipisahkan dengan partisiasi masyarakat. Baik partisipasi yang bersifat sukarela maupun bersifat himbauan/perintah dari pemerintah setempat. Dalam konteks lokus penelitian ini, konsep teori dan realitas yang ada di lapangan menunjukkan adanya suatu relevansi bahwa pembangunan akan berjalan dengan baik apabila ditopang oleh partisipasi seluruh elemen terkait. Adanya partispasi masyarakat akan membuat terlaksananya pembangunan infrastruktur jalan, dengan demikian masyarakat Desa Kaligintung berpartisipasi dengan baik. Terdapat empat jenis partisipasi di Desa Kaligintung yaitu (1) partisipasi dalam pengambilan keputusan, (2) partisipasi dalam pelaksanaan, (3) partisipasi dalam pengambilan manfaat dan (4) partisipasi dalam evaluasi. 
JSPG: Journal of Social Politics and Governance Vol.3 No.1 Juni 2021

\section{FAKTOR YANG MEMPENGARUHI PARTISIPASI MASYARAKAT DALAM PEMBANGUNAN INFRASTRUKTUR DI DESA KALIGINTUNG KECAMATAN TEMON KABUPATEN KULON PROGO}

Partisipasi masyarakat dalam pembangunan infrastruktur merupakan persyaratan utama yang melandasi keberhasilan dalam proses pembangunan, baik di Indonesia pada umumnya dan Desa pada khususnya. Partisipasi sangat bergantung pada kondisi ekonomi, sosial, budaya dan keberadaan lingkungan dari masyarakat yang terlibat, serta tingkat pendidikan masyarakat. Sosial ini maksudnya adalah bahwa para perencana dapat mengetahui bagaimana masyarakat terlibat dalam proses pembangunan, baik dalam faktor: geografis, organisasi, budaya lokal, ekonomi masyarakat serta sosial politik yang berkembang. Adapun di Desa Kaligintung, faktor yang mempengaruhi partisipasi masyarakat terdapat empat point yaitu faktor ekonomi, faktor kesadaran, faktor pendidikan dan faktor penghambat.

Salah satu faktor pendukung masyarakat untuk berpartisipasi dalam pembangunan jalan Desa Kaligintung adalah faktor ekonomi. Karena dengan adanya faktor ekonomi, dapat membuat masyarakat semakin mudah untuk memenuhi kebutuhan hidup. Berdasarkan hasil wawancara, salah satu faktor yang mempengaruhi partisipasi masyarakat dalam pembangunan infrastruktur ialah aspek ekonomi (Koyoga, 2015). Hal ini juga sesuai dengan hasil penelitian, dimana masyarakat dapat merasakan mudahnya melakukan aktifitas perekonomian, seperti para petani yang langsung dapat menjual produknya tanpa campur tangan pemborong, pekerja swasta diberikan kemudahan akses jalan. Karakteristik wilayah perdesaan yang ditinjau dari aspek ekonomi dapat dilihat dari tingkat kesejahteraan dan mayoritas pekerjaan penduduknya. Apabila ditinjau dari aspek ekonomi dan partisipasi masyarakat, karakteristik Desa Kaligintung terletak pada tingkat kesejahteraan penduduk, dimana kesejahteraan masyarakat Desa Kaligintung dapat terlihat dari pertumbuhan ekonomi dan juga didukung oleh pembangunan insfrastruktur jalan desa.

Selanjutnya, suksesnya sebuah pembangunan infrastruktur, tentunya terdapat peran dan campur tangan dari masyarakat sekitar. Seperti yang terjadi di masyarakat Desa Kaligintung, dimana mereka memiliki rasa solidaritas yang tinggi untuk ikut berpartisipasi dan tolong menolong, khususnya dalam pembangunan infrastruktur. Berdasarkan hasil wawancara, perangkat Desa Kaligintung dalam hal ini memiliki kesadaran untuk terbuka kepada masyarakat. Inilah yang menjadi faktor pendukung yang dapat dikatakan penting. Sebab, dengan adanya dukungan dan koordinasi yang baik dari semua pihak, tentunya akan membuat masyarakat lebih semangat untuk ikut berpartisipasi dalam setiap program yang diadakan oleh pemerintah desa, dan tentunya dengan tujuan untuk mensejahterakan masyarakat.

Selain faktor ekonomi dan faktor kesadaran, terdapat satu faktor yang menjadi pendorong masyarakat untuk berpartisipasi dalam pembangunan jalan desa yaitu faktor pendidikan. Masyarakat Desa Kaligintung sangat peduli terhadap pendidikan hal ini dapat dilihat dari salah satu faktor pendukung pembangunan infrastruktur ialah faktor pendidikan. Dalam arti lain memudahkan masyarakat dalam mengakses tempat-tempat pendidikan demi lancarnya anak-anak sekolah sehingga meminimalisir terjadinya keterlambatan, Pendidikan merupakan hal penting yang harus diperjuangkan, oleh 
JSPG: Journal of Social Politics and Governance Vol.3 No.1 Juni 2021

masyarakat secara umum dan orang tua secara khusus. Oleh karenanya, di zaman sekarang pendidikan sangatlah penting, untuk menunjang masa depan anak agar menjadi lebih baik. Terlebih lagi, dengan terealisasinya program pembangunan jalan desa, ini dapat dirasakan betul oleh masyarakat, seperti mudahnya mengakses tempat pendidikan.

Selanjutnya, tentunya ada faktor penghambat yakni ketidaksadaran akan pentingnya pembangunan infrastruktur jalan desa, masih ada salah satu kelompok masyarakat yang masih egois akan kekuasan tanah umum Desa Kaligintung namun hal ini tidak menjadi kendala yang cukup rumit karena hanya segelintir orang saja namun masih banyak orang mengharapkan akan adanya pembangunan infrastruktur jalan. Proses pembangunan insfrastruktur jalan ini berjalan dengan baik dikarenakan ada tiga faktor pendukung yakni faktor ekonomi, faktor kesadaran dan faktor pendidikan yang kuat sehingga akan membuat partisipasi aktif masyakat dengan baik sehingga terealisasinya pembangunan infrastruktur jalan Desa Kaligintung.

\section{E. SIMPULAN DAN SARAN Kesimpulan}

Keberhasilan pembangunan sebuah infrastruktur jalan desa tidak dapat dipisahkan dengan partisiasi masyarakat. Adanya partispasi masyarakat akan membuat terlaksananya pembangunan infrastruktur jalan, dengan demikian masyarakat Desa Kaligintung berpartisipasi dengan baik. Terdapat empat jenis partisipasi di Desa Kaligintung yaitu (1) partisipasi dalam pengambilan keputusan, (2) partisipasi dalam pelaksanaan, (3) partisipasi dalam pengambilan manfaat dan (4) partisipasi dalam evaluasi. Partisipasi masyarakat dalam pembangunan infrastruktur jalan desa dipengaruhi oleh beberapa faktor pendukung dan terdapat pula faktor penghambat. Pada pembangunan infrastruktur jalan Desa Kaligintung terdapat tiga faktor pendukung, yakni 1) faktor ekonomi, dimana ini menjadi penting sebab infrastruktur jalan merupakan sarana utama dalam menjalankan perekonomian. 2) faktor kesadaran, dengan adanya kesadaran dan dukungan dari semua pihak, membuat masyarakat dapat ikut berpartisipasi dengan maksimal. 3) faktor pendidikan, dimana masyarakat Desa Kaligintung sangat peduli dalam hal pendidikan. Selain faktor pendukung, terdapat faktor penghambat, dimana terdapat beberapa kelompok masyarakat yang masih menggunakan bahu jalan desa untuk kepentingan pribadi, namun faktor ini tidak menjadikan tertundanya pembangunan infrastruktur jalan Desa Kaligintung.

\section{Saran}

Partisipasi masyarakat Desa Kaligintung dalam pembangunan infrastruktur jalan perlu ditingkatkan lagi, dan khususnya kepada pemerintah desa yaitu sebagai pelaksana tugas, harus lebih bisa mengoptimalkan keterlibatan masyarakat dalam berbagai program desa pada umumnya dan program pembangunan jalan desa khususnya. Pemerintah Desa Kaligintung perlu memberikan pemahaman mengenai pentingnya pembangunan infrastrukutur, sehingga akan membuat kesadaran masyarakat semakin meningkat. Oleh karena itu, jika muncul faktor penghambat lainnya, maka dapat teratasi dengan mudah dan tentunya pembangunan infrastruktur dapat berjalan dengan baik. 
JSPG: Journal of Social Politics and Governance Vol.3 No.1 Juni 2021

\section{DAFTAR PUSTAKA}

Aprillia Theresia, K. d. (2015). Pembangunan Berbasis Masyarakat. Bandung: Alfabeta.

Huraerah, A. (2008). Pengorganisasian \& Pengembangan Masyarakat: Model \& Strategi Pembangunan Berbasis Kerakyatan. Bandung: Humaniora.

Kalesaran. (2015). PARTISIPASI DALAM PROGRAM NASIONAL PEMBERDAYAAN MASYARAKAT MANDIRI PERKOTAAN KELURAHAN TAAS KOTA MANADO. administrasi publik, IV no. 5.

Kansil, C. S. (2005). Sistem Pemerintahan Indonesia. jakarta: Bumi aksara.

Karina. (2017). Analisis Partisipasi Masyarakat Dalam Pembangunan Infrastruktur di Desa Pao Kecamatan Malangke Barat Kabupaten Luwu Utara. Makasar: Fakultas Ilmu Sosial dan Ilmu Politik Universitas Hasanuddin Makasar.

Kogoya, T. (2015). Partisipasi Masyarakat Terhadap Pembangunan Infrastruktur Jalan Desa di Kabupaten Lanny Jaya Papua. Berkala Ilmiah Efisiensi, 15 Nomor 2.

Moleong. Lexy J. (2017). Metodologi Penelitian Kualitatif. Bandung: PT Remaja Rosdakarya.

Rahayu, M. D. (2018). Partisipasi Masyarakat dalam Pembangunan Infrastruktur di Desa Sinarsari Kecamatan Kalirejo Kabupaten Lampung Tengah. Lampung Tengah: Universitas Lampung.

Rahman. (2018). teori pemerintahan. malang: UB Press.

Sugiyono. (2016). Metode Penelitian Kombinasi (Mixed Methods). Bandung: ALFABETA.

Undang-Undang no 6 tahun 2014 tentang desa .

Undang-Undang Nomor 23 Tahun 2014 Tentang Pemerintah Daerah.
Wahyuddin. (2018). Analisis Partisipasi Masyarakat dalam Pembangunan Desa di Desa Tanah Karaeng Kecamatan Mamuju Kabupaten Gowa. Makassar: Universitas Islam Negeri Alauddin Makassar. 